\title{
7. PERMEABILITY AND CONSOLIDATION CHARACTERISTICS FROM HOLE 949B, NORTHERN BARBADOS RIDGE ${ }^{1}$
}

\author{
W. Brückmann, ${ }^{2}$ K. Moran, ${ }^{3}$ and A.K. MacKillop ${ }^{4}$
}

\begin{abstract}
Low-gradient flow tests and one-dimensional consolidation tests were performed on four samples from Ocean Drilling Program (ODP) Leg 156, northern Barbados Ridge, Hole 949B, to provide direct as well as indirect measures of permeability and stress history. All samples tested show a significant degree of underconsolidation, with overconsolidation ratio (OCR) values decreasing with depth from 0.4 to 0.2 to 0.1 . These low ratios were used to approximate the excess pore pressures within the accreted sediment and the décollement. The largest estimated excess pore-pressure values lie within the interpreted décollement zone at Site 949 and range from 1600 to $1900 \mathrm{kPa}$. Combining results from this study with previous data from Leg 110, two generalized functions of void ratio vs. hydraulic conductivity for high and low permeability sediments are developed that are characteristic for sediments of low and high smectite content. By applying these functions to the Site 671 (ODP Leg 110) porosity profile, it is possible to demonstrate the occurrence of a zone of low permeability immediately above the décollement. This is consistent with the concept that low permeability sediments will develop higher excess pore pressures, and therefore, are more susceptible to shear failure.
\end{abstract}

\section{INTRODUCTION}

Following Deep Sea Drilling Project (DSDP) Leg 78A (Biju-Duval, Moore, et al., 1984) and Ocean Drilling Program (ODP) Leg 110 (Moore, Mascle, et al., 1990), ODP Leg 156 was the third drilling expedition focused on the study of the Barbados accretionary prism where it forms at the leading edge of the Caribbean Plate (Fig. 1). From these previous cruises, the stratigraphy, structure, and sedimentology of the accretionary complex were well defined using coring and conventional wire-line logging techniques (Moore et al., 1988). Unlike these and other previous drilling operations in accretionary prism settings, the main objective of Leg 156 was to experimentally evaluate effects, rates, and cyclicity of fluid flow in the prism. Meeting these objectives required an array of new and experimental tools and techniques (Shipboard Scientific Party, 1995a).

One of the key parameters controlling the rate of fluid flow through the décollement and the prism is the sediment bulk matrix permeability. It is also a crucial parameter in all numerical models of accretionary prism hydrology. Although studies have used core samples to determine matrix permeability (Taylor and Leonard, 1990), the number of measurements is still far too small to provide representative coverage of the different lithologies and structural domains within the Barbados accretionary prism. Another important parameter relevant to our understanding of accretionary prism dynamics is sediment deformation behavior, which is a function of compressibility and strength, as well as the in situ stress conditions or stress history.

In this study, we present test results on samples from Cores 156949B-2X, 15X, 19X, and 22X that contribute to our understanding of permeability, sediment deformation, and stress history. Our findings

${ }^{1}$ Shipley, T.H., Ogawa, Y., Blum, P., and Bahr, J.M. (Eds.), 1997. Proc. ODP, Sci. Results, 156: College Station, TX (Ocean Drilling Program).

${ }^{2}$ GEOMAR Research Center Marine Geosciences, Kiel, Federal Republic of Germany.wbrueckmann@geomar.de

Geological Survey of Canada, Bedford Institute of Oceanography, Box 1006, Dartmouth, Nova Scotia B2Y 4A2, Canada.

${ }^{4}$ Ocean Drilling Program, Texas A\&M University Research Park, 1000 Discovery Drive, College Station, TX 77845-9547, U.S.A. are compared and combined with previous results from Leg 110 with the aim of predicting the permeability variations for the variety of sediment types within the modern accretionary complex.

\section{METHODS}

Whole-round core samples, each $12 \mathrm{~cm}$ long, were cut from the core sections during the cruise. To prevent moisture loss, all samples were capped, sealed, and kept upright in refrigerated seawater until immediately before testing. The samples were cut, trimmed, and extruded into thin-walled rings with a bevelled cutting edge. After cutting the samples to a height of $\sim 2 \mathrm{~cm}$, they were transferred to a consolidation ring and placed between two porous filter stones and mounted into a back-pressured consolidometer.

In this study, two different methods were used to determine hydraulic conductivity: low-gradient flow tests and one-dimensional consolidation tests. Whereas the low-gradient permeability tests provide a direct measurement of the sediment hydraulic conductivity, expressed as the coefficient of permeability $(K)$, one-dimensional consolidation tests define sediment compressibility, from which permeability can be estimated indirectly. One-dimensional consolidation tests also define the individual sample stress history, which can than be related to stress histories inferred from porosity-depth functions.

\section{Low-gradient Permeability}

The sediment property that describes the rate of fluid flow is hydraulic conductivity, or Darcy's coefficient of permeability. They are related by

$$
K=k \rho g / \mu \text {, }
$$

where $K$ is hydraulic conductivity, $k$ is intrinsic permeability, $\rho$ is pore-fluid density, $g$ is gravitational acceleration, and $\mu$ is fluid viscosity. Hydraulic conductivity testing in the laboratory typically involves the use of a constant-head permeameter, a falling-head permeameter, or a constant flow permeameter. In our study we have used a low flow-rate pump to measure hydraulic conductivity. This 
A
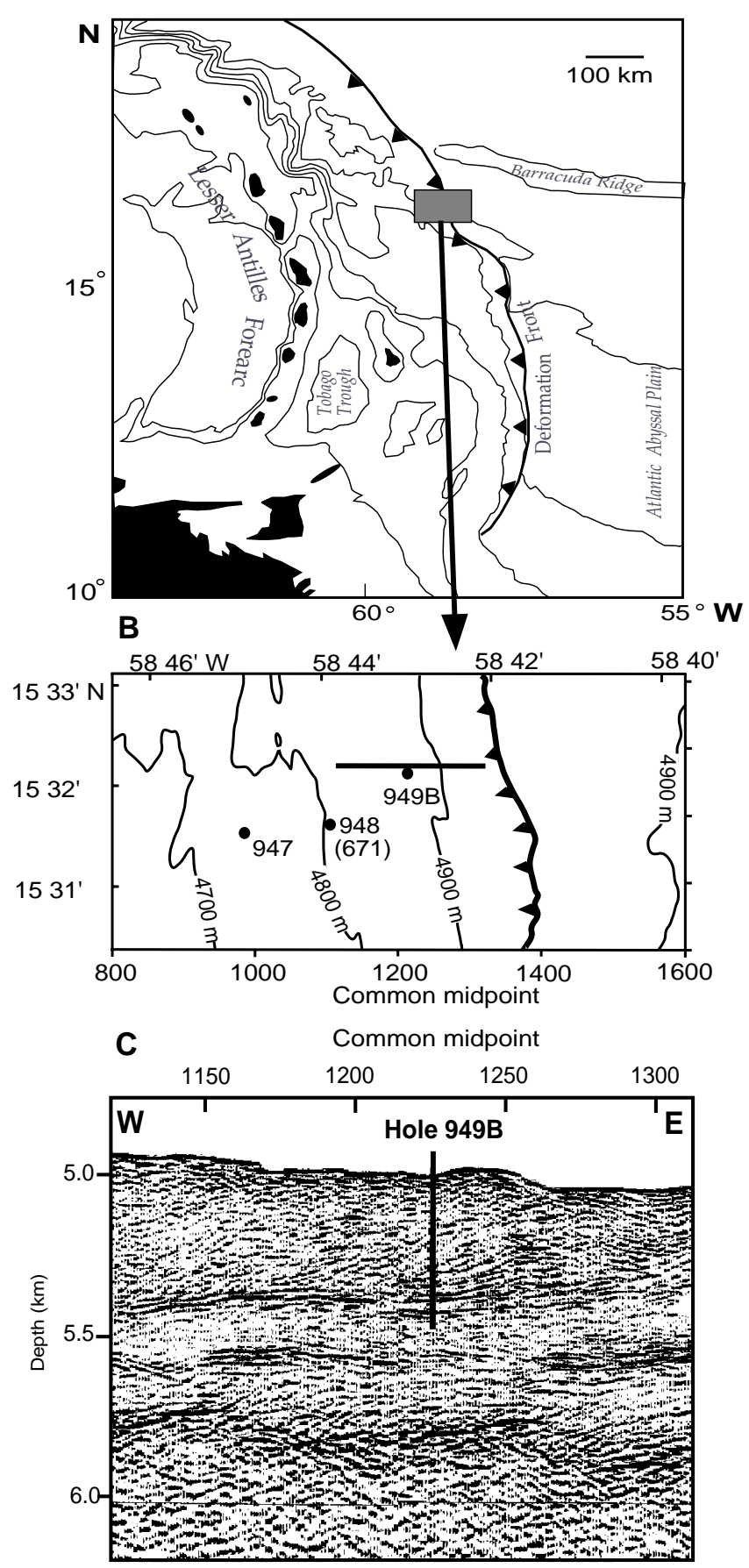

Figure 1. Location map. A. Index chart of the Lesser Antilles. Shaded zone indicates the extent of the Barbados Ridge accretionary prism. B. Location map showing ODP Legs 156 and 110, and DSDP Leg 78A drill sites. Depth contours are based on the evaluation of three-dimensional seismic data. Solid line indicates position of seismic section shown below (from Shipboard Scientific Party, 1995b). C. Seismic section through the Site 949 area (from Shipboard Scientific Party, 1995b).

technique establishes a precisely controlled rate of flow through a sample within a closed, saturated system. The known rate of flow replaces the requirement for measuring flow rate. A differential pressure transducer measures the resulting gradient across the sample. All permeability results are reported as hydraulic conductivity values and can be converted to intrinsic permeability using Equation 1.

\section{One-dimensional Consolidation Tests}

The term consolidation is used in many contexts, often incorrectly. In geologic literature this term is frequently used to suggest a degree of cohesiveness within a sedimentary unit, perhaps better regarded as the degree of lithification. In this study, consolidation is defined, following Terzaghi (1943), as the change in the volume of voids within saturated sediment that results from a decrease in water content. Consolidation tests were completed using a back-pressured consolidometer, incrementally loaded at a load increment ratio of one, following procedures described by MacKillop et al. (1995). The tests are used to determine the preconsolidation stress, $\left(P_{c}\right)$, which is interpreted as the maximum past stress. $P_{\mathrm{c}}{ }^{\prime}$ is determined using the Casagrande construction method (Holtz and Kovacs, 1981) and is compared with the overburden stress $\left(P_{0}{ }^{\prime}\right)$, calculated from the sediment column buoyant unit weight. This comparison is expressed as the overconsolidation ratio (OCR) or $P_{c}^{\prime} / P_{o}^{\prime}$ '. Permeability values are also estimated from the consolidation tests by analyzing the incremental load data using Terzaghi's one-dimensional consolidation theory, which relates the coefficient of consolidation, $\left(c_{v}\right)$ to hydraulic conductivity. At each consolidation load increment, $c_{v}$ is determined and used to estimate hydraulic conductivity as follows:

$$
K=c_{v} \rho g a_{v} / 1+e_{o}
$$

where $e_{o}$ is initial void ratio, and $a_{v}$ is the slope of the incremental load-displacement curve.

\section{RESULTS \\ Consolidation}

Three consolidation tests were completed on cores from Hole 949B. Hole 949B core recovery was low, with an average of $40 \%$ (Shipboard Scientific Party, 1995a). Total penetration was completed to a depth of $464.2 \mathrm{~m}$ below seafloor (mbsf), covering an interval starting at $244.1 \mathrm{mbsf}$ that penetrated several thrust faults and the décollement at $458 \mathrm{mbsf}$. The lithostratigraphy is defined by compilation of data from all of the holes at Site 949 (Shipboard Scientific Party, 1995b) and is divided into three lithologic units. The upper Unit I is defined by only one core as a hemipelagic, bioturbated clay with ash interbeds. Based on the seismostratigraphy, Unit I is inferred to be $160 \mathrm{~m}$ thick and ranges in age from early Pleistocene to late Miocene. Unit II, from 244 to $431 \mathrm{mbsf}$, is predominantly a hemipelagic claystone that varies in color from gray to brown over an age of early to late Miocene. Unit III, from 431 to $464.2 \mathrm{mbsf}$, is a hemipelagic, mottled claystone with laminated siltstone and gray claystone. The base of Unit III is of late Oligocene age.

All three consolidation samples from Site 949 (156-949B-15X-5, $30 \mathrm{~cm}, 156-949 \mathrm{~B}-19 \mathrm{X}-1,40 \mathrm{~cm}$, and 156-949B-22X-1, $135 \mathrm{~cm})$ are within lithostratigraphic Unit II. Very low $P_{c}{ }^{\prime}$ values (Fig. 2) indicate significant underconsolidation. The most striking observation in the consolidation data is the dramatic decrease in $P_{c}{ }^{\prime}$ with decreasing porosity or void ratio, suggesting increasing underconsolidation (excess pore pressure) with depth below seafloor within Unit II. When presented in terms of OCR, the values are small, less than one (the normally consolidated state), and decrease with depth with OCRs of 0.4 , 0.2 , and 0.1 . These values are comparable to those measured previously at Barbados from Leg 110 (Taylor and Leonard, 1990) and at other modern accretionary complexes (Moran et al., 1993; and Moran et al., 1995).

\section{Permeability}

Low-gradient permeability was measured on the consolidation test samples at selected load increments. In addition, one narrowdiameter sample (156-949B-2X-2, $72 \mathrm{~cm}$ ) was tested for permeability in a triaxial cell using the low-flow pump system and following 

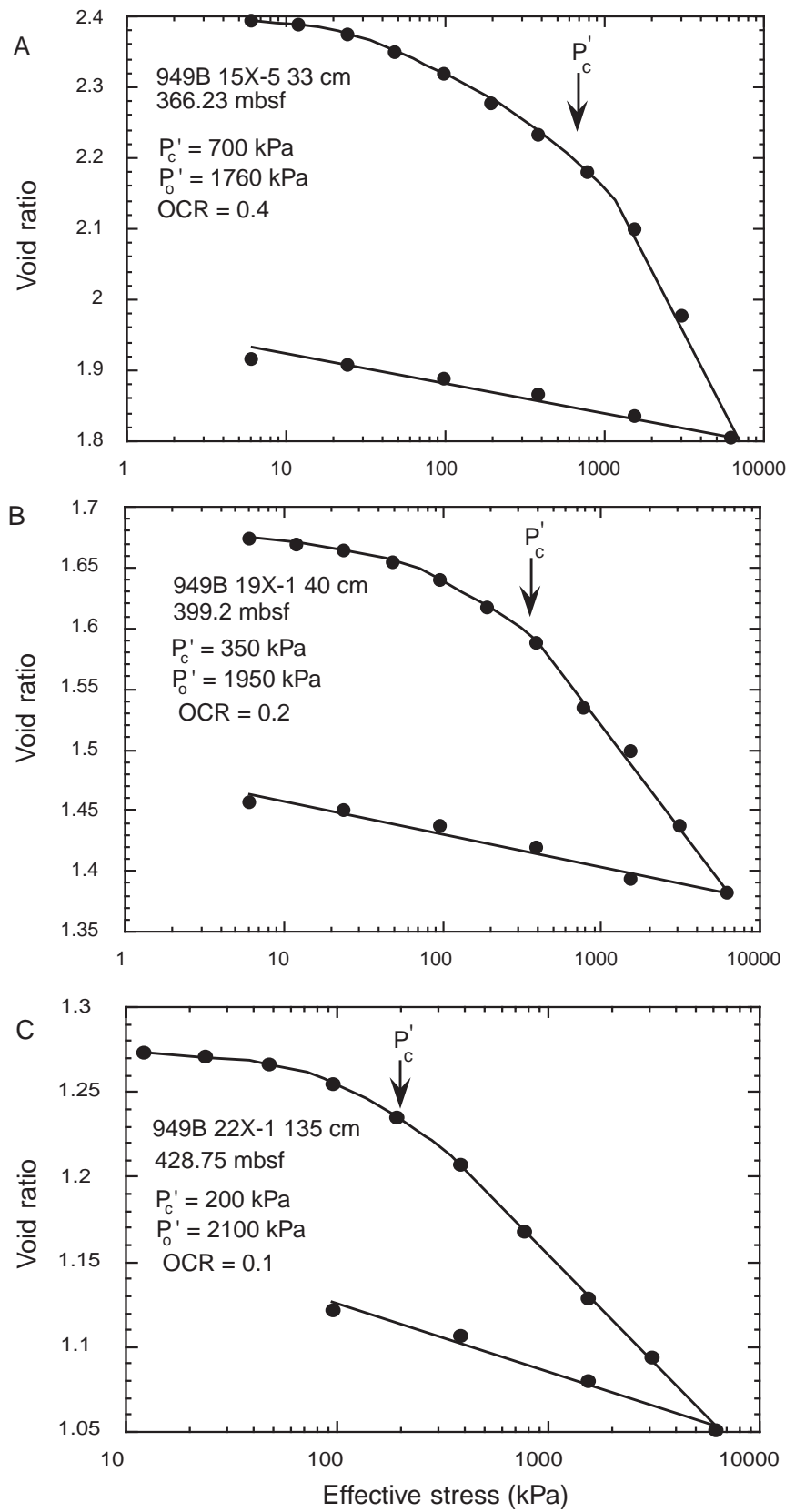

Figure 2. One-dimensional consolidation test results presented as log effective stress vs. void ratio plots. A. Sample 156-949B-15X-5, $33 \mathrm{~cm}$. B. Sample 156-949B-19X-1, 40 cm. C. Sample 156-949B-22X-1, $135 \mathrm{~cm}$.

the same procedures as the consolidation samples. For the triaxial test, permeability was measured at one load increment (consolidation stress). In all other tests at each flow rate interval, fluid was pumped through the sample in both directions. Hydraulic conductivity was determined at incremental void ratios using three flow rates. Darcy flow was established for each test as seen by the linear relationship of flow velocity as a function of hydraulic gradient (Fig. 3). Based on Darcy's law, the slope of these linear curves is the hydraulic conductivity. For each test, the hydraulic conductivity, $(K)$, varies as a loglinear function with void ratio (Fig. 4).

The measured values are compared with estimates from the compression vs. time data for each consolidation load increment using Equation 2. These estimates are usually good for higher permeability sediments and diverge from the measured values at low permeabilities. For the samples tested here, the estimates from consolidation data are fairly good for Sample 156-949B-15X-5, $33 \mathrm{~cm}$ (Fig. 4), and are lower than the measured values for Samples 156-949B-19X-1, 40 $\mathrm{cm}$ (Fig. 4), and 156-949B-22X-1, $135 \mathrm{~cm}$ (Fig. 4).

Although individual functions of permeability are useful for understanding variability at a fine scale, more generalized characterization of permeability functions are needed for accretionary prism studies. We develop a generalized function by compiling permeability data for the northern Barbados Ridge that are estimated from onedimensional consolidation tests from a previous study (Taylor and Leonard, 1990). The hydraulic conductivity data are presented as a function of void ratio and show two distinct generalized relationships (Fig. 5). The function that defines the sediment with lower hydraulic conductivity from Figure 5 is

$$
\mathrm{e}=6.1+0.44 \log K
$$

and the higher hydraulic conductivity sediment function is

$$
\mathrm{e}=5.0+0.45 \log K
$$

The range of hydraulic conductivity values is consistent with previously reported values for homogeneous clays (e.g., Holtz and Kovacs, 1981).

\section{DISCUSSION}

The overconsolidation ratios derived for the three samples are useful indicators of stress history and pore pressure. Results from consolidation tests from Site 949 yield low OCR values that decrease with depth from 0.4 at 366 mbsf to 0.1 at 439 mbsf, suggesting a high degree of underconsolidation. This apparent increase in underconsolidation with depth, in turn, suggests a similar rise in excess pore pressure. Because the OCR values decrease primarily as a function of preconsolidation stress, rather than simply as a result of increasing overburden stress, the excess pore-fluid pressure in the sediment is most likely increasing with depth. The largest difference in $P_{c}{ }^{\prime}$ among the sample depths (Fig. 2) is between the shallowest sample (366 mbsf; $P_{c}{ }^{\prime}=700 \mathrm{kPa}$ ) and the mid-depth sample (399 mbsf; $P_{c}{ }^{\prime}=350$ $\mathrm{kPa})$. The Shipboard Scientific Party (1995b) defines three structural domains for Hole 949B: a prism domain (0- 390 mbsf), a décollement domain ( 390-448 mbsf), and an underthrust domain $(\sim 448$ mbsf to the bottom of the hole). The large difference in $P_{c}{ }^{\prime}$, and thus, excess pore pressures, occurs between the prism domain and the décollement domain. This suggests that higher excess pore pressure occurs within the décollement. Excess pore pressure can be approximated using the difference between the normally consolidated $P_{c}{ }^{\prime}$ (effective overburden stress) and the measured $P_{c}^{\prime}$.' Using this method, the excess pore pressure within the décollement at Site 949 is estimated to be $1600-1900 \mathrm{kPa}$. This estimate is supported by results from packer tests conducted at Site 949C where significant overpressures have been inferred from a series of formation shut-in and flow tests (Fisher and Zwart, Chapter 15, this volume).

Hydraulic conductivity, and thus permeability, is one of the most important parameters controlling the development of excess fluid pressures in these geological settings (Bredehoeft and Hanshaw, 1968). Low-permeability zones serve to concentrate high excess pore pressures, reducing the effective stress into zones of potential weakness. At Barbados, we are able to show two unique relationships of permeability as a function of void ratio (Fig. 5). The lower permeability function (Eq. 3) is representative of sediment with smectite content in excess of $60 \%$ (Taylor and Leonard, 1990; Brown and Ransom, 1996), whereas the higher permeability function (Eq. 4) is characteristic of sediment with smectite contents below $60 \%$. Applying these functions to index property data from Leg 110, Site 671, from intervals of the respective smectite content (Brown and Ransom, 1996), a continuous permeability function with depth is predict- 
A
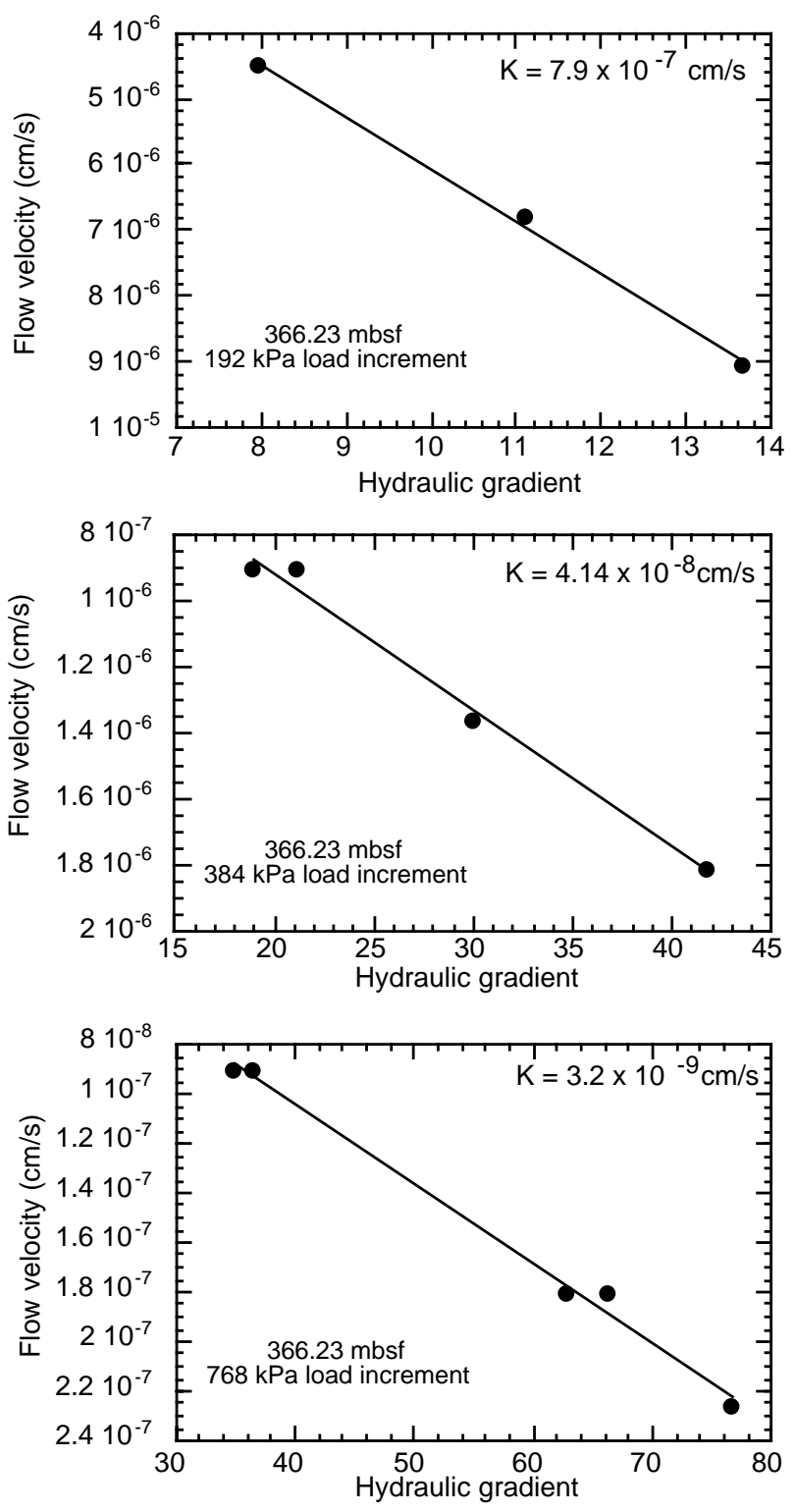

B
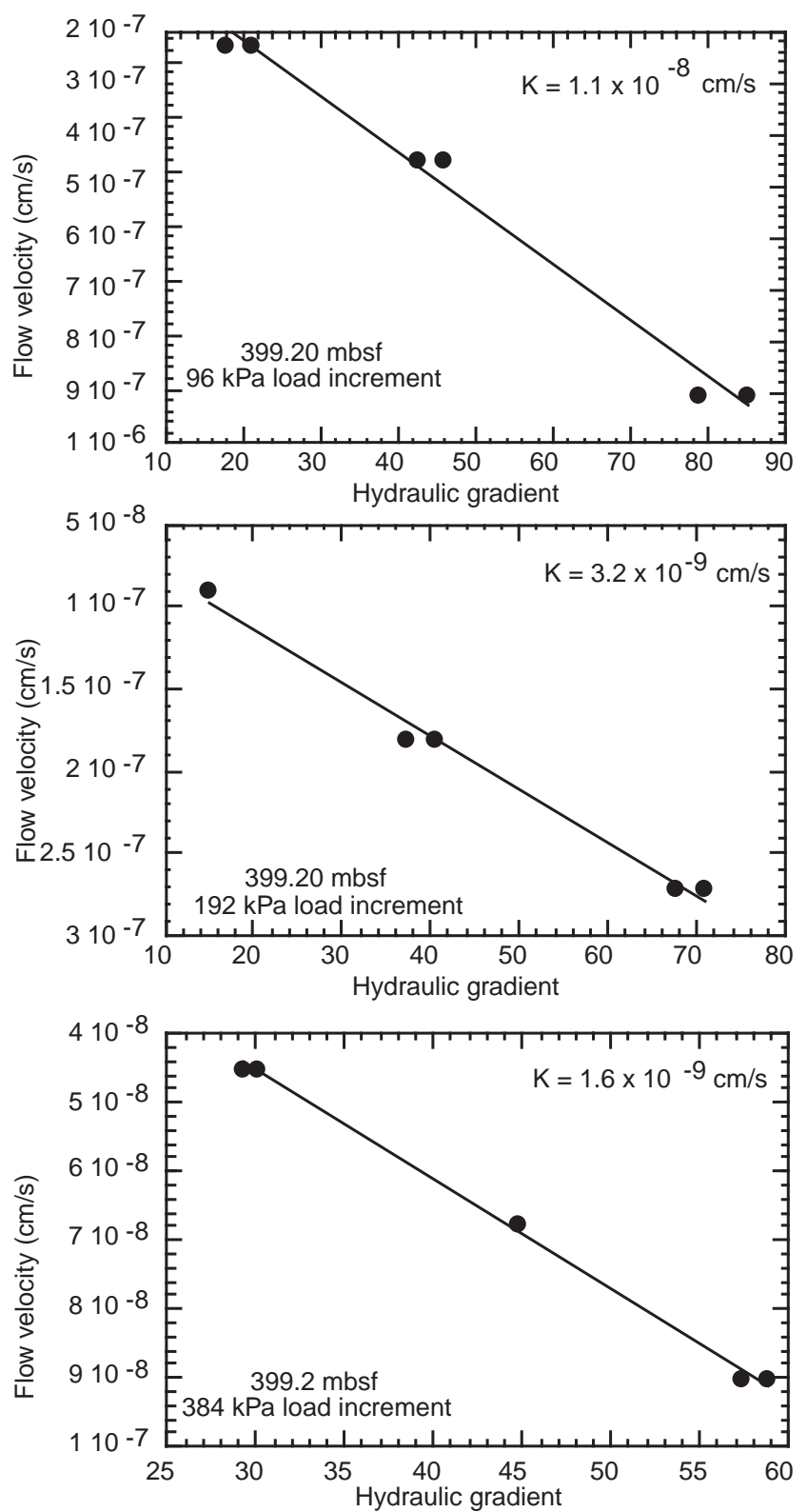

Figure 3. Results from low-gradient permeability tests presented as log flow velocity vs. hydraulic gradient plots for various load increments in each sample. A. Flow velocity vs. hydraulic gradient for the 192,384 , and $768 \mathrm{kPa}$ load increment in Sample 156-949B-15X-5, $33 \mathrm{~cm}$, permeability test. B. Flow velocity vs. hydraulic gradient for the 96, 192, and $384 \mathrm{kPa}$ load increment in Sample 156-949B-19X-1, $40 \mathrm{~cm}$, permeability test. C. Flow velocity vs. hydraulic gradient for the 192, 384, and $768 \mathrm{kPa}$ load increment in Sample 156-949B-22X-1, $135 \mathrm{~cm}$, permeability test. D. Flow velocity vs. hydraulic gradient for the $10 \mathrm{kPa}$ load increment in Sample 156-949B-2X-2, $72 \mathrm{~cm}$, permeability test.

ed. In addition, intrinsic permeability, $k$, was calculated for this prediction using Equation 1 and temperature data measured from Site 948 (Fig. 6) for the calculation of pore-fluid viscosity. One of the lowest permeability zones occurs over the depth interval just above the active décollement at Site 671 from 420 to 510 mbsf. Another low-permeability zone occurs at the base of the interval drilled at Site 671. These low-permeability zones are probably also the intervals of the highest excess pore pressure. This interpretation is consistent with the development of the position of the décollement at Site 671 (and Site 948) and the proto-décollement at Site 672 (Fig. 1). The zones of high smectite content represent the intervals of lowest permeability. As accretion and deformation proceed, increased loading from convergence and thrusting causes excess pore pressures to develop. The zones of highest excess pore pressure develop over the intervals of lowest permeability. These zones are then the most susceptible to failure and, consequently, the major failure surface, the décollement, forms at the base of the zone where the highest pore pressure occurs.

\section{SUMMARY}

The sediment recovered from the accretionary prism at Site 949 displays underconsolidated behavior as seen by the very low overconsolidation ratios. These low ratios are used to approximate the excess pore pressures within the accreted sediments and within the décollement. The largest estimated excess pore pressure values lie 
C
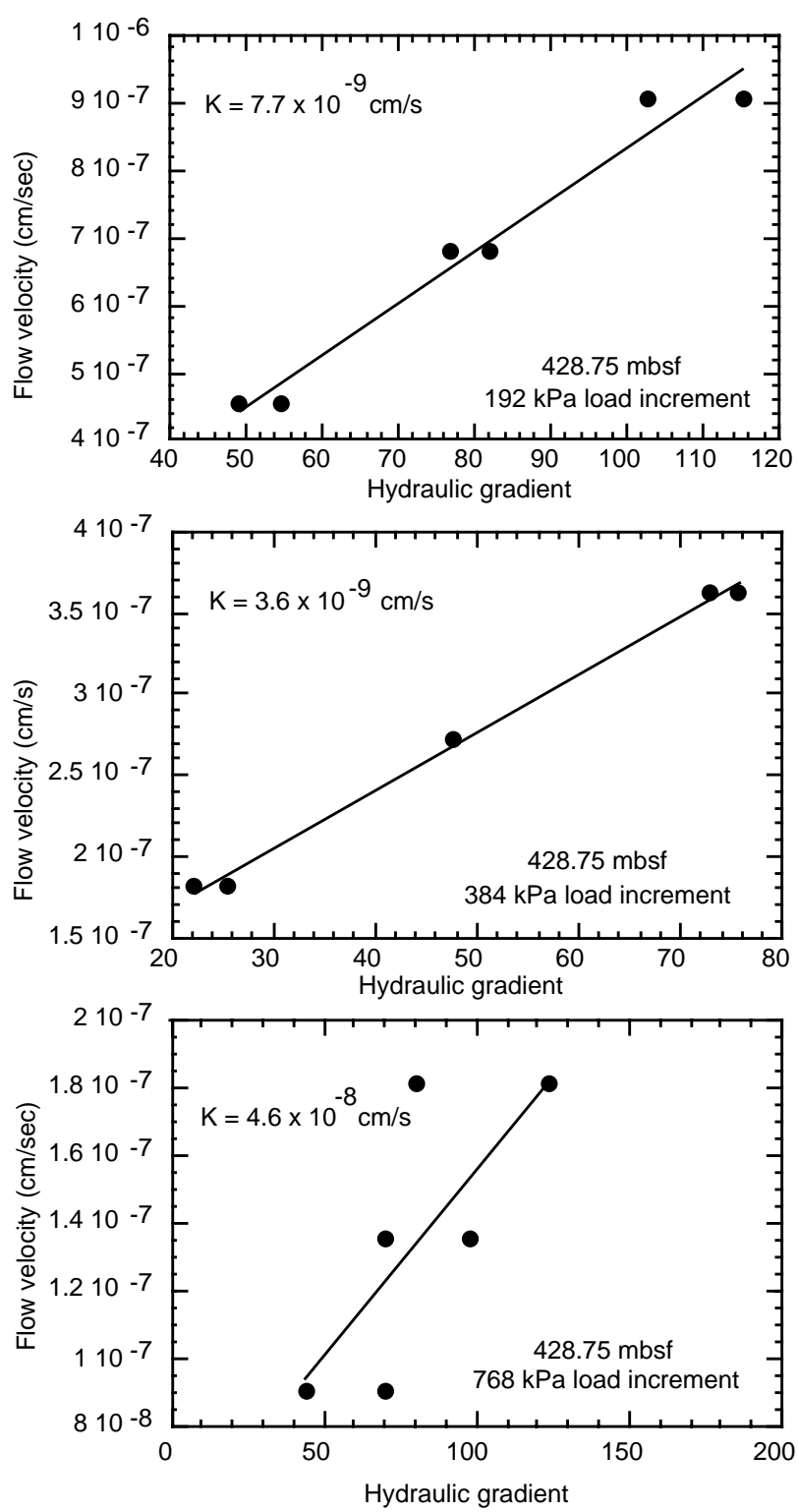

D

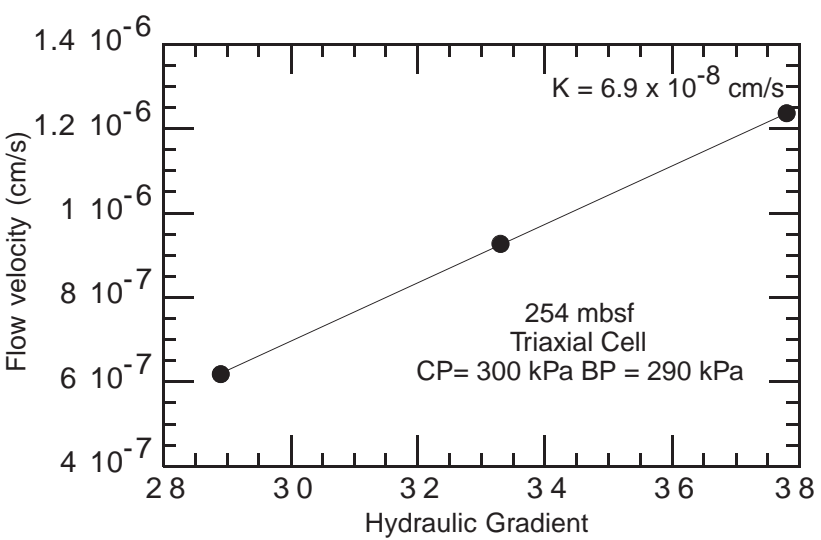

Figure 3 (continued). within the interpreted décollement zone at Site 949 and range from 1600 to $1900 \mathrm{kPa}$.

Permeability data show a bimodal behavior, which is likely controlled by clay mineral composition. Smectite-rich sediment has very low permeabilities when compared with sediment that consists of $<50 \%$ smectite. We suggest that these low permeability sediments will develop higher excess pore pressures and therefore are more susceptible to failure. At Sites 949, 948, and 671, the zone of highest smectite composition (and thus lowest permeability) lies within or just above the present décollement. In addition, the zone of highest smectite content at Site 672 coincides with the so-called "proto-décollement," $6 \mathrm{~km}$ in front of the deformation front.

\section{ACKNOWLEDGMENTS}

The authors gratefully acknowledge technical assistance provided by Kate Jarrett and Stephanie Banks. Financial support was provided by Deutsche Forschungsgemeinschaft (DFG) through Grant Br 1075$5 / 1$. Additional support was provided by a grant from the German Canadian Friendship Fund (BZ 200 U/Geo 49). The manuscript benefited from comments and suggestions of two anonymous reviewers.

\section{REFERENCES}

Biju-Duval, B., Moore, J.C., et al., 1984. Init. Repts. DSDP, 78A: Washington (U.S. Govt. Printing Office).

Brown, K.M., and Ransom, B., 1996. Porosity corrections for smectite-rich sediments; impact on studies of compaction, fluid generation, and tectonic history. Geology, 9:843-846.

Bredehoeft, J.D., and Hanshaw, B.B., 1968. On the maintenance of anomalous fluid pressures: 1 . Thick sedimentary sequences. Geol. Soc. Am. Bull., 79:1097-1106.

Holtz, R.D., and Kovacs, W.D., 1981. An Introduction to Geotechnical Engineering: Englewood Cliffs, NJ (Prentice-Hall).

MacKillop, A.K., Moran, K., Jarrett, K., Farrell, J., and Murray, D., 1995. Consolidation properties of equatorial Pacific Ocean sediments and their relationship to stress history and offsets in the Leg 138 composite depth sections. In Pisias, N.G., Mayer, L.A., Janacek, T.R., Palmer-Julson, A., and van Andel, T.H. (Eds.), Proc. ODP, Sci. Results, 138: College Station, TX (Ocean Drilling Program), 357-369.

Moore, J.C., Mascle, A., et al., 1990. Proc. ODP, Sci. Results, 110: College Station, TX (Ocean Drilling Program).

Moore J.C., Mascle, A., Taylor, E., Andreieff, P., Alvarez, F., Barnes, R., Beck, C., Behrmann, J., Blanc, G., Brown, K., Clark, M., Dolan, J., Fisher, A., Gieskes, J., Hounslow, M., McLellan, P., Moran, K., Ogawa, Y., Sakai, T., Schoonmaker, J., Vrolijk, P., Wilkens, R., and Williams, C., 1988. Tectonics and hydrogeology of the northern Barbados Ridge: results from Ocean Drilling Program Leg 110. Geol. Soc. Am. Bull., 100:1578-1593.

Moran, K., Brückmann, W., Feeser, V., Campanella, R.G., 1993. In-situ stress conditions at the Nankai Trough, Site 808. In Hill, I.A., Taira, A., Firth, J.V., et al., Proc. ODP, Sci. Results, 131: College Station, TX (Ocean Drilling Program), 283-291.

Moran, K., Gray, W.G.D., and Jarrett, C.A., 1995. Permeability and stress history of sediment from the Cascadia Margin. In Carson, B., Westbrook, G.K., Musgrave, R.J, and Suess, E. (Eds.), Proc. ODP, Sci. Results, 146 (Pt. 1): College Station, TX (Ocean Drilling Program), 275-280.

Shipboard Scientific Party, 1995a. Introduction. In Shipley, T.H., Ogawa, Y. Blum, P., et al., Proc. ODP, Init. Repts., 156: College Station, TX (Ocean Drilling Program), 3-11.

, 1995b. Site 949. In Shipley, T.H., Ogawa, Y. Blum, P., et al., Proc. ODP, Init. Repts., 156: College Station, TX (Ocean Drilling Program), 193-257.

Taylor, E., and Leonard, J., 1990. Sediment consolidation and permeability at the Barbados forearc. In Moore, J.C., Mascle, A., et al., Proc. ODP, Sci. Results, 110: College Station, TX (Ocean Drilling Program), 289-308.

Terzaghi, K., 1943. Theoretical Soil Mechanics: New York (Wiley).

Date of initial receipt: 18 February 1996

Date of acceptance: 25 July 1996

Ms 156SR-015 

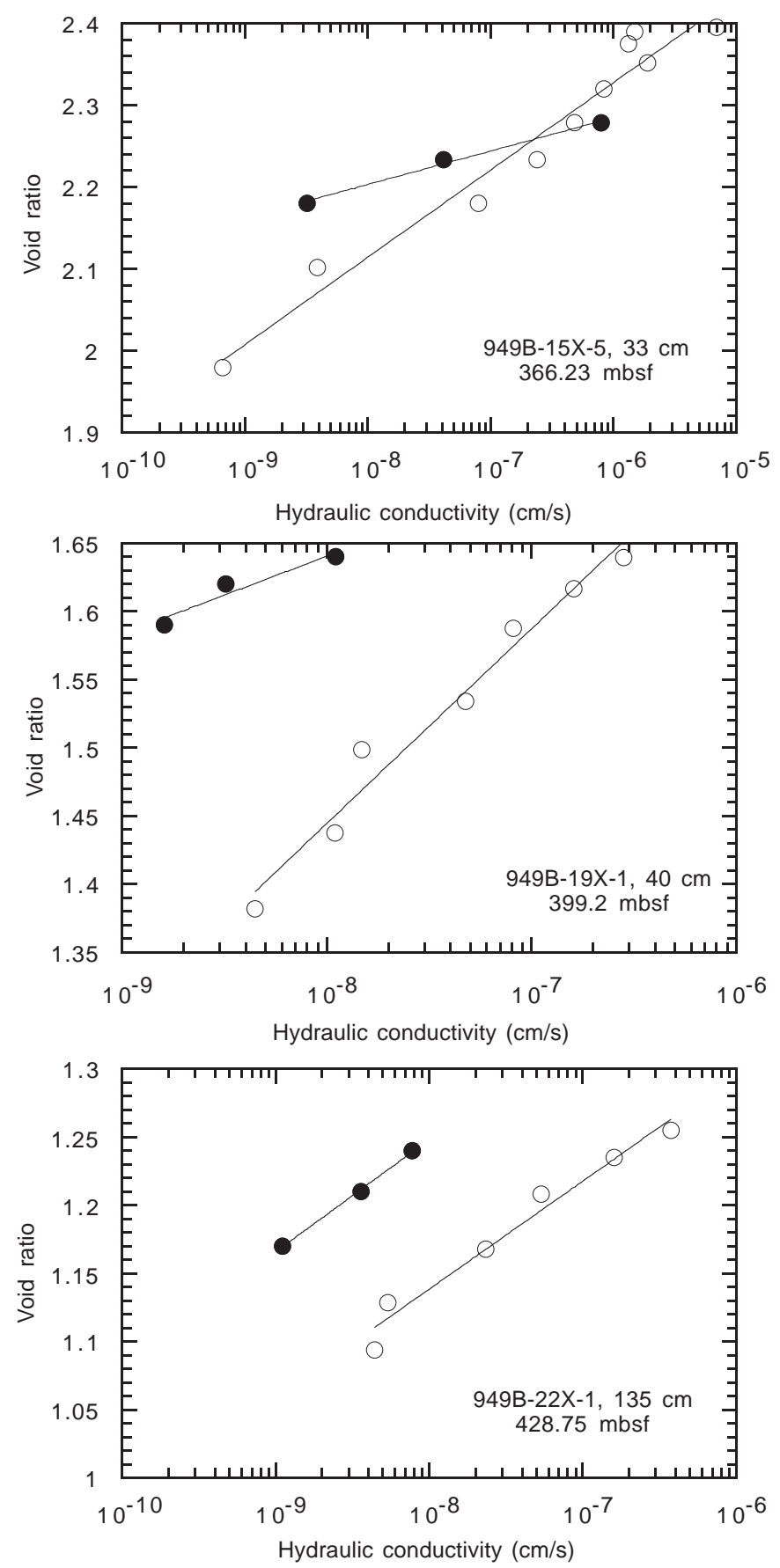

Figure 4. Comparison of permeability results from low-gradient tests (solid symbols) and estimates from the compression vs. time data for each consolidation load increment (open symbols).

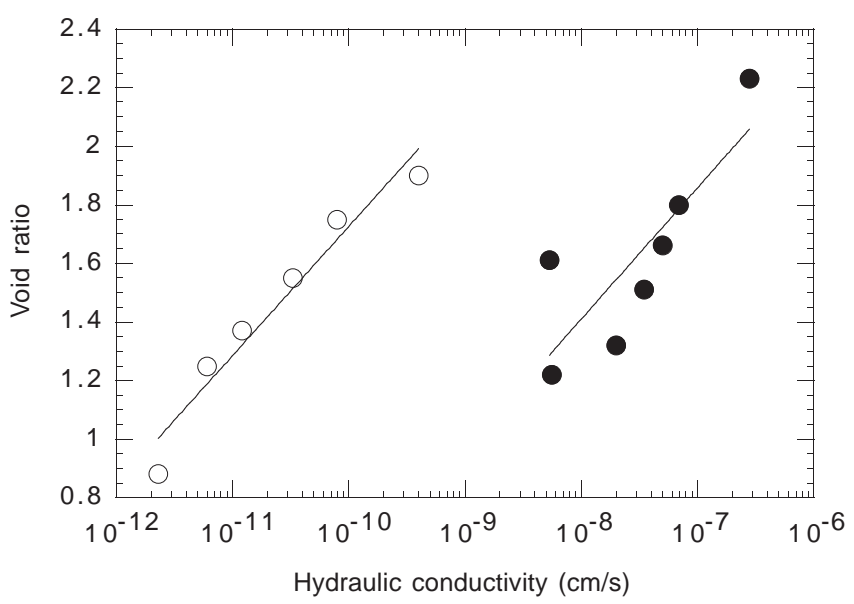

Figure 5. Hydraulic conductivity test results from this study and interpreted from Taylor and Leonard (1990) tests: 671D-NAC-1; 671D-NAC-2, 671C1X-1-A; 672-19X-3; 671B-7H-3; 671B-7H-4; 671B-10H-3; 671B-10H-4. Solid circles define higher permeability function (Eq. 4), and open circles define lower permeability function (Eq. 3), as discussed in the text.

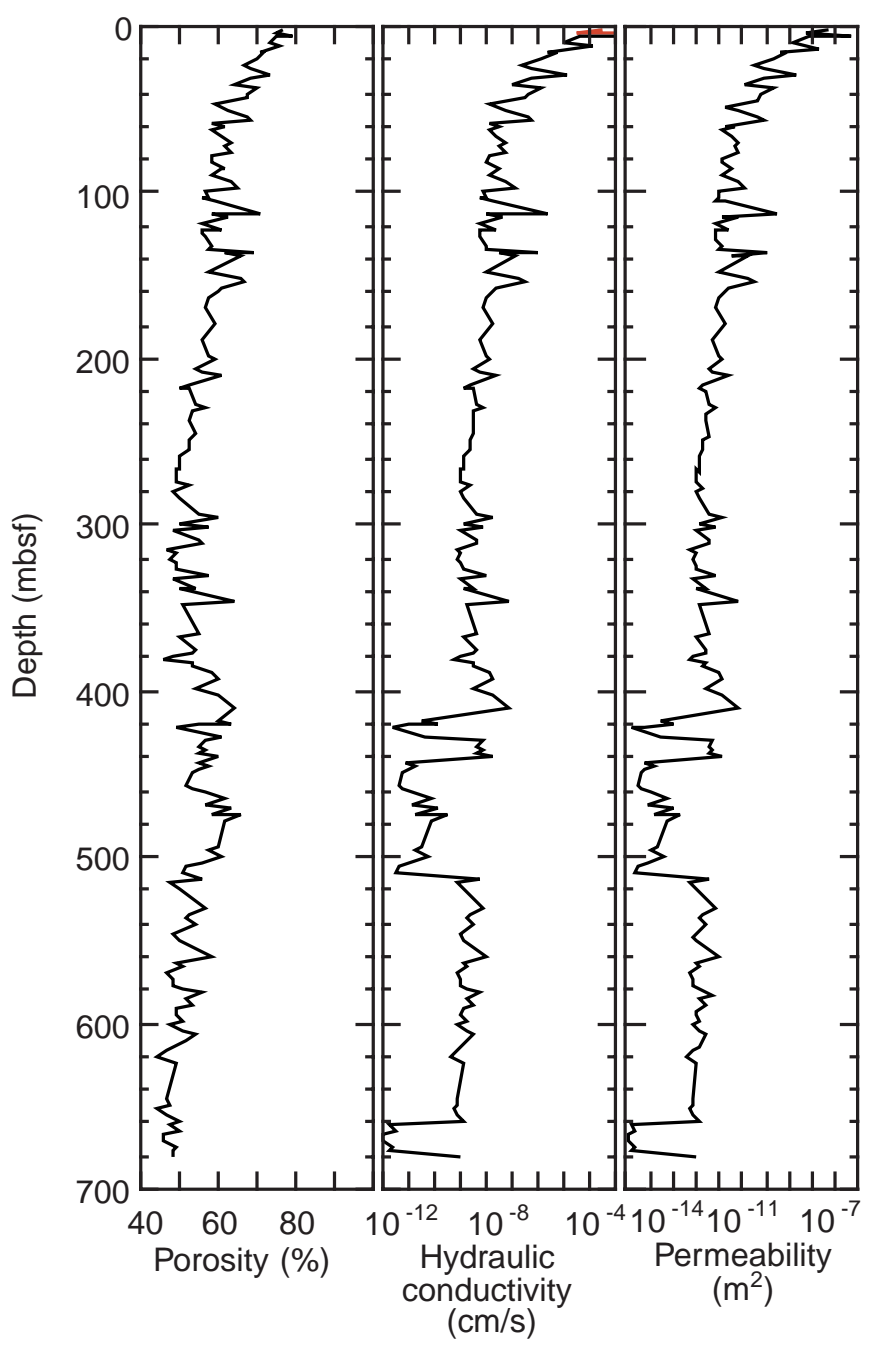

Figure 6. Leg 110, Site 671 laboratory-derived porosity compared with predicted hydraulic conductivity and permeability. 